\title{
JUVENTUDE, IMAGEM E CIDADE: EXPERIÊNCIAS DE PESQUISA ETNOGRÁFICA COM JOVENS URBANOS EM PORTO ALEGRE
}

\author{
Guillermo Stefano Rosa Gómez ${ }^{1}$ \\ Jose Luis Abalos Junior ${ }^{2}$ \\ Manoel Cláudio Mendes Gonçalves da $\operatorname{Rocha}^{3}$
}

\section{Introdução}

$\mathrm{O}$ artigo em questão apresenta reflexões em torno de uma produção coletiva em pesquisa etnográfica, que foi realizada em parceria entre os membros associados do Núcleo de Pesquisa em Antropologia Visual (Navisual/PPGAS/UFRGS) e os discentes da disciplina de Antropologia Visual e da Imagem no curso de Ciências Sociais da Universidade Federal do Rio Grande do Sul (UFRGS/Porto Alegre/RS/Brasil) ${ }^{4}$. O presente trabalho pretende explorar três experiências etnográficas desenvolvidas neste processo, que têm em comum a aproximação junto a grupos jovens em Porto Alegre - as Batalhas de MCs, as trajetórias e itinerários de jovens skatistas, e o evento Feira de Hip Hop propondo uma abordagem imagética em torno do tema das "intervenções artísticas urbanas", tendo em vista compreender as formas sensíveis (Sansot, 1983; 1996; Ledrut, 1984; Rocha, 1995) através das quais estes sujeitos experienciam, praticam e transformam o viver urbano.

A elaboração e realização da disciplina de Antropologia Visual se deu em caráter coletivo no âmbito do Navisual. Professores, estudantes e demais pesquisadores desenvolveram de forma conjunta a proposta de disciplina, o acompanhamento e sua concretização ao longo do semestre, bem como o desenvolvimento de exercícios etnográficos em grupos de trabalho com os alunos, tomando por base a perspectiva teóricometodológica da Antropologia Visual e da Imagem ${ }^{5}$. Na sequência da conclusão do

\footnotetext{
${ }^{1}$ Universidade Federal do Rio Grande do Sul, Brasil.

${ }^{2}$ Universidade Federal do Rio Grande do Sul, Brasil.

${ }^{3}$ Universidade Federal do Rio Grande do Sul, Brasil.

${ }^{4}$ Disciplina ofertada no primeiro semestre de 2016 sob a coordenação da professora Dra. Cornelia Eckert.

${ }^{5}$ Além do material explorado em sala de aula, foi intenso o diálogo com os trabalhos produzidos pelo Banco de Imagens e Efeitos Visuais (BIEV/IFCH/UFRGS), projeto financiado pelo CNPq e que é coordenado pelas professoras Ana Luiza Carvalho da Rocha e Cornelia Eckert.
} 
semestre letivo, deu-se início o processo de produção de uma expografia compartilhada, experiência que também será relatada em seguida e ao longo deste trabalho.

O Navisual situa-se no Laboratório de Antropologia Social do Instituto de Filosofia e Ciências Humanas (IFCH), na UFRGS, e é coordenado pela professora Dra. Cornelia Eckert.

Integram o núcleo professores, estudantes de graduação e pós-graduação, pesquisadores e demais interessados advindos de diferentes áreas de conhecimento, que, de forma dinâmica e alternada, vão compondo esse grupo heterogêneo e plural há mais de vinte anos. Trata-se de um espaço histórico de pesquisa, formação e divulgação de projetos de etnografia visual e de discussões sobre o uso de técnicas audiovisuais na pesquisa antropológica. O Núcleo visa refletir os campos conceituais e fomentar o desenvolvimento teórico e metodológico, principalmente, da Antropologia Visual em interface direta com a Antropologia Urbana (Projeto Navisual, 2016).

Categorias como cidade, memória coletiva e imagem se articulam na perspectiva da “etnografia da duração", principal matriz das produções de pesquisas do núcleo, tendo em vista a parceria com o Banco de Imagens e Efeitos Visuais (BIEV/IFCH/UFRGS). A partir de uma sólida base teórica ${ }^{6}$, desenvolvem-se os trabalhos com as coleções etnográficas e a organização do material produzido ao longo das etnografias em termos de um "banco de conhecimento", o que tem por objetivo compor um "patrimônio etnográfico" (Rocha e Eckert, 2013) que se torne público e acessível aos mais diversos grupos e coletivos como forma de restituição do fazer antropológico.

A exposição foi promovida após concluídas as atividades letivas da disciplina Antropologia Visual, e recebeu o título de "Etnografias compartilhadas: narrativas visuais e sonoras do viver urbano em Porto Alegre". A realização de sua montagem conformou mais uma etapa do processo de ensino-aprendizagem (Rocha e Eckert, 2014b) que envolveu as atividades do Núcleo de pesquisa, o desenvolvimento da disciplina, as experiências etnográficas dos grupos de trabalho e, finalmente, a exposição ${ }^{7}$. A organização das fotos em

\footnotetext{
${ }^{6}$ A etnografia da duração (Rocha e Eckert 2013b) segue inspirações da fenomenologia das imagens e a filosofia da imaginação criadora (Bachelard, 1978; 1988; 2010); do estruturalismo figurativo e a antropologia do imaginário (Durand 1980; 1995; 2002); da fenomenologia da memória e da tensão narrativa a partir da obra de Paul Ricoeur $(1991 ; 1994 ; 2007)$, da sociologia formal simmeliana e suas reflexões sobre o tema da cidade (Simmel, 1979; 1983; 2005), o que conduz também para uma antropologia das formas sensíveis (Sansot, 1983; 1996; Ledrut, 1984; Rocha, 1995), dentre outras perspectivas, a antropologia das sociedades complexas (Velho, 1981; 1994).

${ }^{7}$ Vale destacar que a exposição não encerra o processo, tendo em vista sua continuidade: vários grupos de trabalho ainda mantém interlocução com os sujeito e coletivos junto aos quais desenvolveram os respectivos exercícios etnográficos. A experiência rendeu inclusive temas para o desenvolvimento dos trabalhos de
} 
narrativas, vinculadas a um processo etnográfico, enfrentou novas problemáticas, bastante pragmáticas: a resolução e dimensões físicas das fotos, os modos de disposição, e os materiais utilizados, por exemplo.

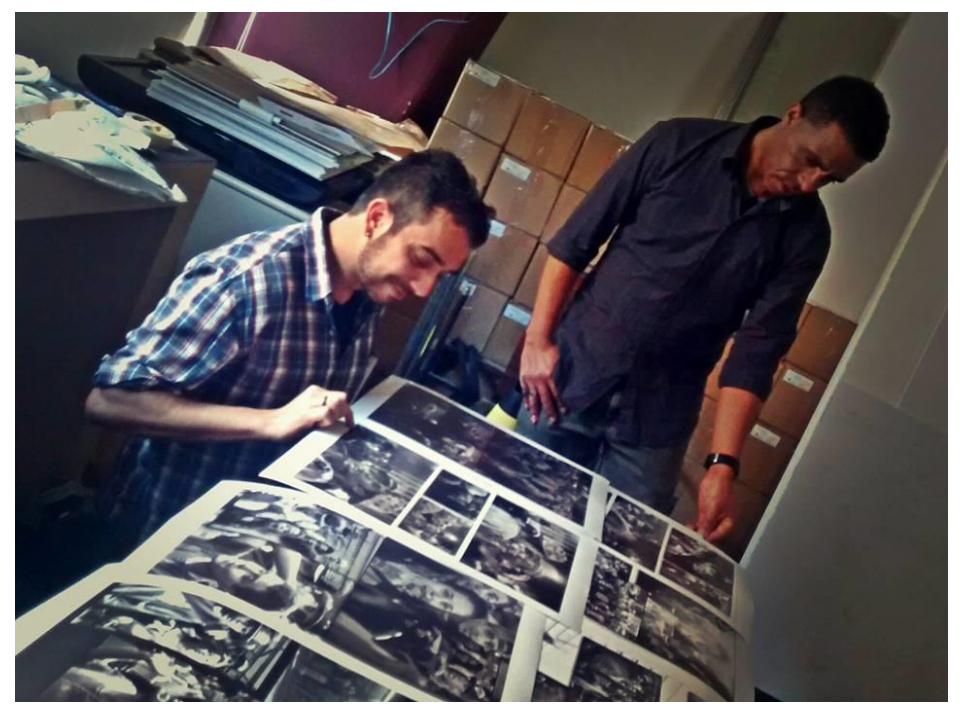

Jose Luis (esq.) e Gilmar (dir.) - Foto: 2016.

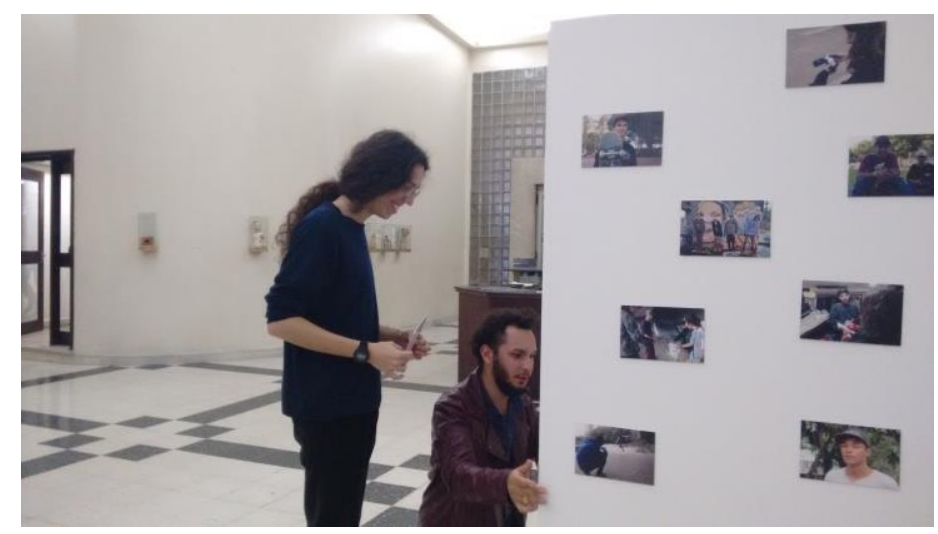

Guillermo(esq.) e Ânderson (dir.), montagem - Foto: Carmem Guardiola. 2016.

conclusão de curso de alguns dos estudantes da disciplina, temas de pesquisa no âmbito de bolsas de iniciação científica, teses de doutorado, entre outras parcerias. 
Cada grupo tinha a responsabilidade de dar um tratamento narrativo a seu material produzido: como as imagens (fotográficas, fílmicas, sonoras) dialogavam entre si e se conectavam com a experiência vivida com os sujeitos ao longo do trabalho de campo? Era necessária, portanto, uma coerência narrativa ligada ao "dinamismo criador" (Durand, 1989; Rocha e Eckert, 2015) que mobilizaria uma convergência entre as "constelações de imagens" (Durand, 1989; Rocha e Eckert, 2015) no interior de cada proposta etnográfica com o eixo temático "formas sensíveis do viver urbano", "núcleo semântico organizador de sentido" (Durand, 1989; Rocha e Eckert, 2015) que centralizava a proposta expográfica como um todo. As orientações acompanharam de perto as criações dos roteiros de saída de campo, do pré-projeto (exercícios de etnografia urbana e visual), do projeto (envolvendo criação de narrativas visuais, organizadas a partir de categorizações e coleções), e do pósprojeto (croquis de seus projetos expográficos, montagem e desmontagem da exposição, escrita de texto para o catálogo da exposição).

A exposição necessitava de uma "identidade comum". Logo o esforço se viu multiplicado, quando a escala das negociações imagéticas colocou em interação os nove grupos. Neste processo, foi fundamental a existência de um outro personagem: o curador, Rafael Derois ${ }^{8}$. Por meio de reuniões com cada um dos grupos e seus orientadores, Rafael tomou conhecimento de todo o material produzido e organizou a exposição, em termos de aproximações e distanciamentos temáticos, características estéticas e núcleos de sentido. Esboçou-se, portanto, um resultado intrínseco de diálogo dos materiais de campo com a organização de uma prática expográfica.

O processo só foi possível pois se inseriu em um projeto de maior âmbito, o Unifoto, iniciativa que busca abarcar projetos culturais que envolvam a produção visual e artística de membros da comunidade acadêmica da UFRGS, mas também de toda a população de Porto Alegre.

\footnotetext{
${ }^{8}$ Antropólogo e membro do Departamento de Difusão Cultural da UFRGS.
} 


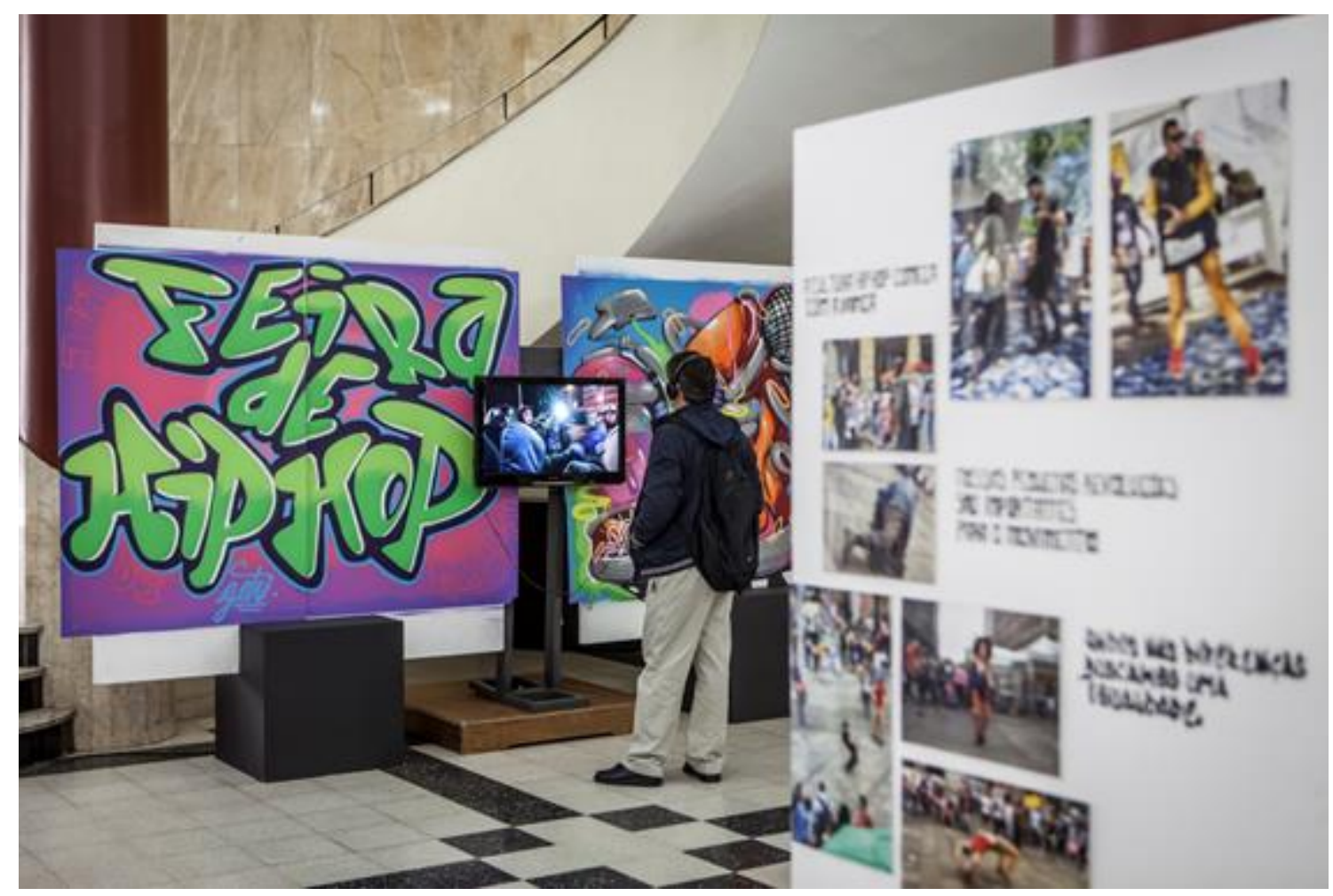

Painéis do Hip Hop, na televisão, crônicas fílmicas do Skate e Batalha de MC’s - Foto: Fabricio Barreto.

O diálogo que esboçamos neste artigo materializou-se primeiramente na própria organização da exposição, derivado de nossas proximidades temáticas e empíricas, resultando em um circuito interno à expografia no qual os materiais produzidos pelos três grupos formavam uma zona de pertencimento. Mas de quais grupos e quais eixos temáticos estamos falando? O primeiro relato tem como pano de fundo as práticas das "Batalhas do Mercado" organizada por uma série de jovens ligados a cultura Hip Hop no centro de Porto Alegre e reflete sobre os limites e êxitos de uma experiência de ensino-aprendizagem em antropologia visual. Segue-se um relato sobre uma experiência junto a skatistas, mergulhando na trajetória e itinerários de um jovem praticante do esporte da zona metropolitana da capital gaúcha. Por fim, apresentamos a Feira do Hip Hop, evento realizado mensalmente por artistas e coletivos vinculados à cultura Hip Hop na Esquina Democrática em Porto Alegre. 
Uma das aproximações que emerge ao longo dos relatos etnográficos diz respeito à questão do uso dos espaços públicos (Leite, 2002) ${ }^{9}$ por jovens que realizam uma mobilidade periferia-centro (Magnani, 2013). Os itinerários urbanos de jovens na cidade representam uma dimensão de mobilidade presente nos relatos apresentados. O fato da Batalha de MCs levar o nome e ocorrer no Mercado Público de Porto Alegre, espaço histórico de confluência de todos bairros e da região metropolitana, relaciona-se a uma estratégia de localização que facilita a vinda de MCs de todos cantos da cidade. Já a experiência junto a skatistas, demonstra que o deslocamento pode ser sinônimo de aperfeiçoamento técnico e progressão dentro do esporte, pois possibilita o acesso a pistas com obstáculos mais elaborados ou que têm maior projeção no "cenário". O que podemos observar também na realização da Feira do Hip Hop, na qual os participantes deslocam-se de diferentes bairros periféricos para a Esquina Democrática, mobilizando consigo diferentes formas criativas de praticar o espaço urbano em direção a um ponto específico no centro da cidade onde vibram memórias, resistências e lutas cotidianas.

Estes deslocamentos de jovens urbanos aqui apresentados nas especificidades dos relatos também nos levam a pensar também uma estética da competição marcadamente presente nas formas de sociabilidades juvenis, que entrelaça aspectos agonísticos e lúdicos. Nas batalhas de MCs a experiência das disputas de "sangue" que envolvem trocas de insultos e categorias acusatórias são parte onipresente do saber fazer do freestyle ${ }^{10}$, dos campeonatos de skate e das disputas dinâmicas dos quatro elementos constituintes do Hip Hop que culminam em um dia de Feira na Esquina Democrática. São, portanto, algumas destas "relações de aproximação" nos circuitos jovens (Magnani, 2005) aqui explorados que nos motivaram a apresentar uma discussão dialógica entre estas três pesquisas.

\footnotetext{
${ }^{9}$ Rogério Proença Leite (2002) tem como eixo de trabalho a distinção entre espaço urbano e espaço público para evitar sobreposições conceituais que muitas vezes tem confundido a noção de espaço público com a de espaço urbano aberto. Para o autor "embora o espaço público se constitua, na maioria das vezes, no espaço urbano, devemos entendê-lo como algo que ultrapassa a rua; como uma dimensão socioespacial da vida urbana, caracterizada fundamentalmente pelas ações que atribuem sentidos a certos espaços da cidade e são por eles influenciadas. Não sendo necessariamente todo espaço urbano um espaço público, há de se verificar quando um espaço urbano pode ser caracterizado como público.

${ }^{10}$ No que se refere ao jogo de rimas na "arte de duelar com palavras" há diversos estudos e inclusive uma linha de pesquisa dentro da antropologia que se debruça a entender esse tipo de fenômeno social. Uma visão geral de jogos de duelos verbais aponta que estes se caracterizam pela agressividade e pela troca de insultos como meio de sociabilidade. Marco Jacquemet, em uma revisão de conflitos verbais para a Encyclopedia of Language and Linguistics, define duelos verbais como "o câmbio competitivo de insultos geralmente obscenos entre pelo menos duas partes" (Jacquemet, 2005: 17).
} 
Aproximações que podemos traduzir também em termos de imaginários da juventude, pois envolvem uma dimensão imagética e sensível mobilizada por estes jovens no interior de constelações de imagens que, simultaneamente, são materializadas e organizadas na extensão dos percursos da fala narrada, da rima improvisada, dos pés sobre o shape do skate, dos corpos que dançam em meio ao ritmo da rua, da fotografia, vídeo e som capturados no smartphone ou câmera digital.

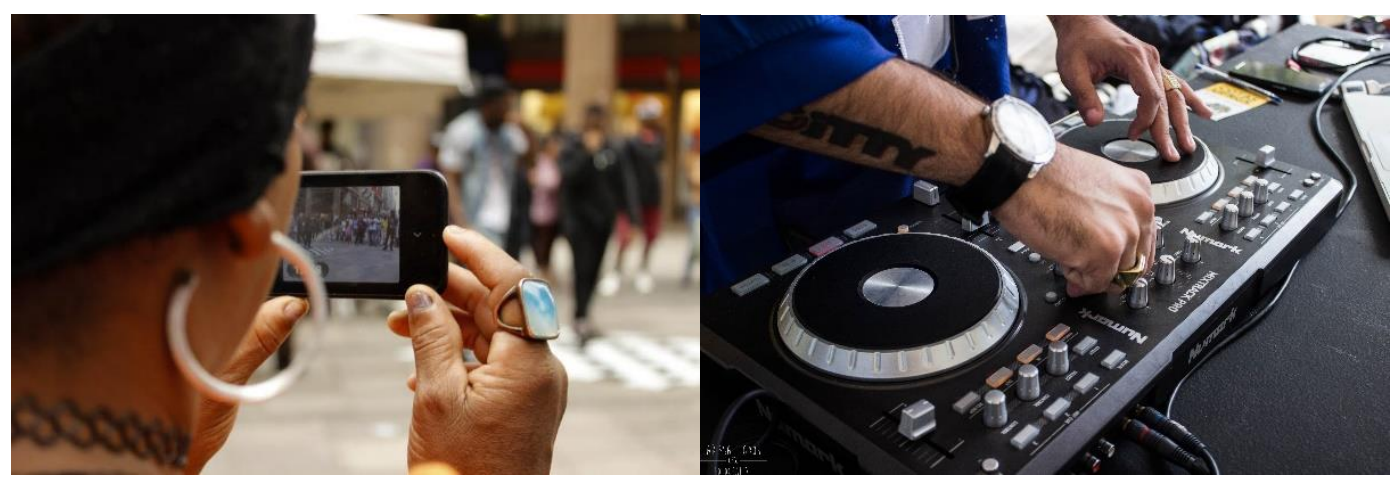

Fotos: Larissa Signor. 2016.

\section{As Batalhas de MCs e a estética da noite}

O grupo formado por Gilmar Santos, Simone Azambuja, Francisco Gonzaga e Ellen Tabarkiewicz teve a coordenação de Jose Luis Abalos Junior. Em princípio houve alguma dificuldade em delimitar um objeto de pesquisa que se inserisse dentro das "intervenções artísticas urbanas", eixo de sentido principal que daria "liga" aos trabalhos produzidos por todos os grupos na disciplina. O que pesquisar dentro desse universo de possibilidades? Foi essa a questão colocada em um primeiro momento quando todos sentaram enquanto grupo. Gilmar comentou que gostaria de pesquisar algo inserido na questão étnica, pois este seria seu tema de trabalho final de graduação. Simone, que faz graduação em Artes Visuais e solicitou a disciplina como aluna especial, mostrou-se flexível às possibilidades de temáticas que fossem sugeridas. Já Francisco e Franciele se mostraram interessados em estudar manifestações vinculadas a cultura do Hip Hop. Neste sentido, baseado na experiência de produção de um trabalho final de graduação em Ciências Sociais, José Luís sugeriu a pesquisa sobre as "Batalhas de MCs" que aconteciam em Porto Alegre. Este 
objeto de pesquisa parecia contemplar os diferentes interesses dos integrantes do grupo além de ser logisticamente viável para pesquisa etnográfica com imagens.

A primeira saída de campo realizada coletivamente foi na "Batalha do Mercado", evento que ocorre nos últimos sábados do mês, ao lado do Mercado Público Municipal de Porto Alegre. Como já esperado, ocorreram algumas dificuldades como segurança dos equipamentos, horários em comum entre os integrantes do grupo e o tempo chuvoso. Nesta saída estiveram presentes Gilmar e Simone que estavam muito curiosos para entender o como se organizavam as batalhas. Gilmar relatou suas impressões em seu diário de campo:

\begin{abstract}
A expectativa de ir a campo é muito grande, principalmente quando se têm pouca experiência no ramo, uma série de dúvidas e perguntas nos vêm à cabeça. Exemplo: como será a minha intervenção? Vai dar tudo certo? Como vou captar o propósito da pesquisa com o grupo de estudo? Vamos ser bem aceitos pelo grupo e nossos interlocutores, entre outras questões que surgem. (Diário de Campo de Gilmar, 17 de Maio de 2016).
\end{abstract}

A Batalha do Mercado é um evento ligado a cultura Hip Hop que aglutina muitos jovens que fazem freestyle e vêm "batalhar" no centro da cidade. Trata-se de um espaço que diz muito da construção da cidade de Porto Alegre e é alvo de muitas pesquisas relacionadas à memória coletiva ${ }^{11}$. Todos os últimos sábados do mês, às $22 \mathrm{~h}, \mathrm{MC}$ 's de diversos lugares da cidade e da região metropolitana ocupam um determinado espaço geográfico: em frente às escadarias do Chalé da Praça XV e o final da linha de ônibus da Praça Pereira Parobé. De um lado está o Mercado Público e o reformado Largo Glênio Peres, de outro, está à esquina da Avenida Voluntários da Pátria.

\footnotetext{
${ }^{11}$ Muitas são as pesquisas relacionadas à memória coletiva que tem como objeto o epicentro simbólico da cidade onde está inserido o Mercado Público municipal de Porto Alegre. Ana Luiza Carvalho da Rocha no documentário etnográfico "A Tradição do Bará do Mercado" traz os relatos de sujeitos de matriz africana sobre o fundamento afro-religioso chamado O Bará do Mercado Público, a partir dos percursos e experiências urbanas desses negros na cidade de Porto Alegre.
} 


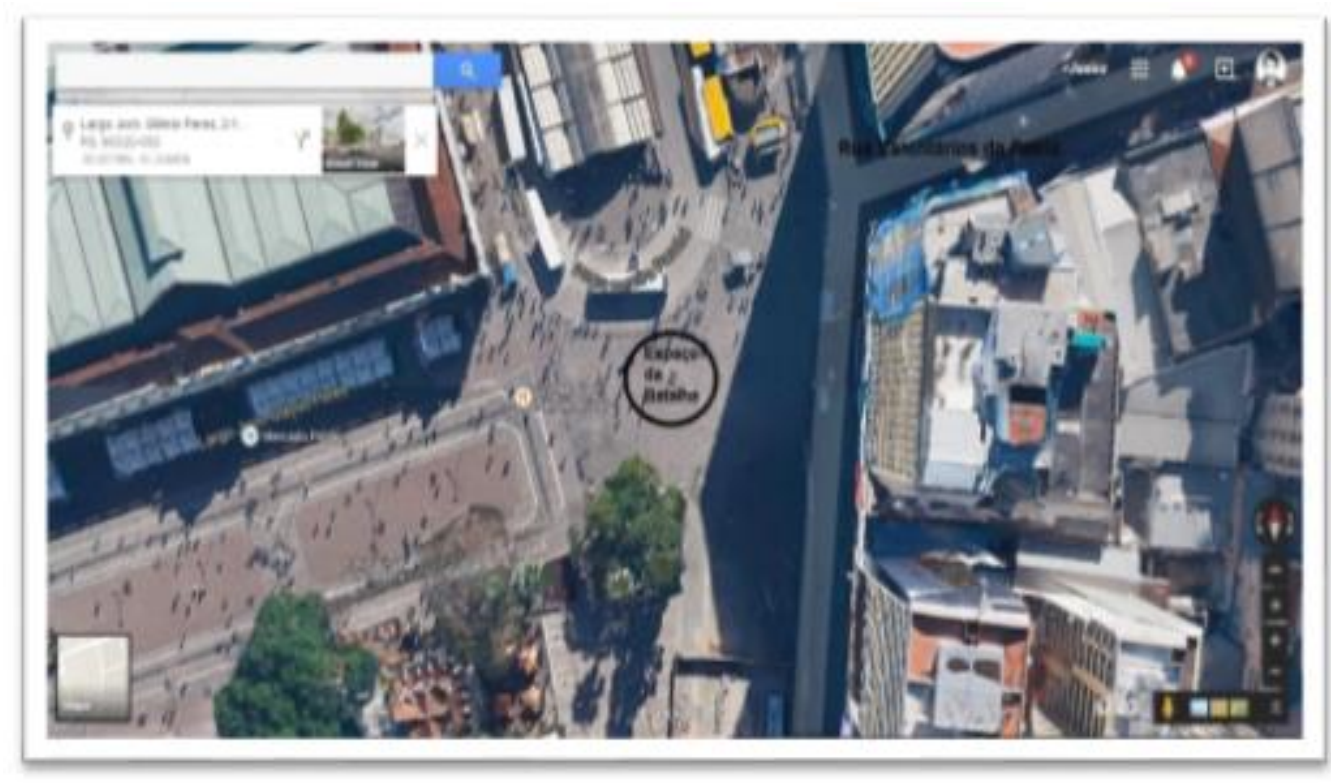

Espaço no centro de Porto Alegre onde ocorre o evento da "Batalha do Mercado". Fonte: Google Maps

Realizada no epicentro da cidade, cercada de locais onde vibram memórias da cidade e ambiências prenhes de significado histórico, a manifestação cultural acontece sempre à noite, quando o lugar se torna um cenário de outras sociabilidades. O que no dia é caracterizado pela movimentação massiva de pessoas, a noite se revela um espaço de poucos caminhantes: a rítmica da rua que se esvazia, escurece, oculta. Ritmo que se rompe, porém, quando passam a ser praticadas atividades de lazer, divertimento e prazer. Entre estas atividades noturnas se destaca a aglomeração de alguns jovens cantores de RAP já conhecidos na cidade. Há também as interações - ora evidentes, ora de maneira mais discreta - que ocorrem num circuito entre o lícito e ilícito, tais como a compra e venda de bebidas alcoólicas e substâncias ilícitas. Esta "estética noturna" de apropriação de determinados espaços da cidade por seus jovens habitantes diz muito do entendimento do que são as Batalhas do $\mathrm{MCs}^{12}$.

Dentro das dinâmicas desta expressão o objetivo do que vale nas batalhas é a rapidez de construir os versos de acordo com o tema escolhido e a capacidade de empolgar a plateia e o "júri" (compostos por outros MCs ou participantes do evento) que irá escolher o vencedor em cima da lógica do improviso e rima. Os MCs precisam de um domínio

\footnotetext{
${ }^{12}$ Uma presença que marca o lugar, mas que não se relaciona diretamente como o evento das Batalhas de MCs é o circuito de prostituição, aspecto característico dos arrabaldes do Mercado Público Municipal.
} 
verbal, um certo conhecimento geral, histórico e capacidade de construir rimas lógicas e com ritmo, poesia e comunicação com o público presente.

A estética noturna, as roupas largas e bonés, a performance dos MCs em meio a uma batalha eram elementos interessantes a serem captados visualmente pelas câmeras. Mas, dentro da pluralidade de elementos significativos visualmente, o que fotografar? Essa dúvida surgiu após a primeira reunião de nosso grupo depois de uma saída exploratória. Combinados de levar todas as fotografias que tiramos impressas em forma de miniaturas, pois só depois de ver todo o material em conjunto poderíamos partir das formas sensíveis (Rocha \& Eckert, 2013) das Batalha do Mercado. Sendo assim o encontro foi realizado na Faculdade de Educação onde havia mesas para que as imagens fossem vistas em conjunto.
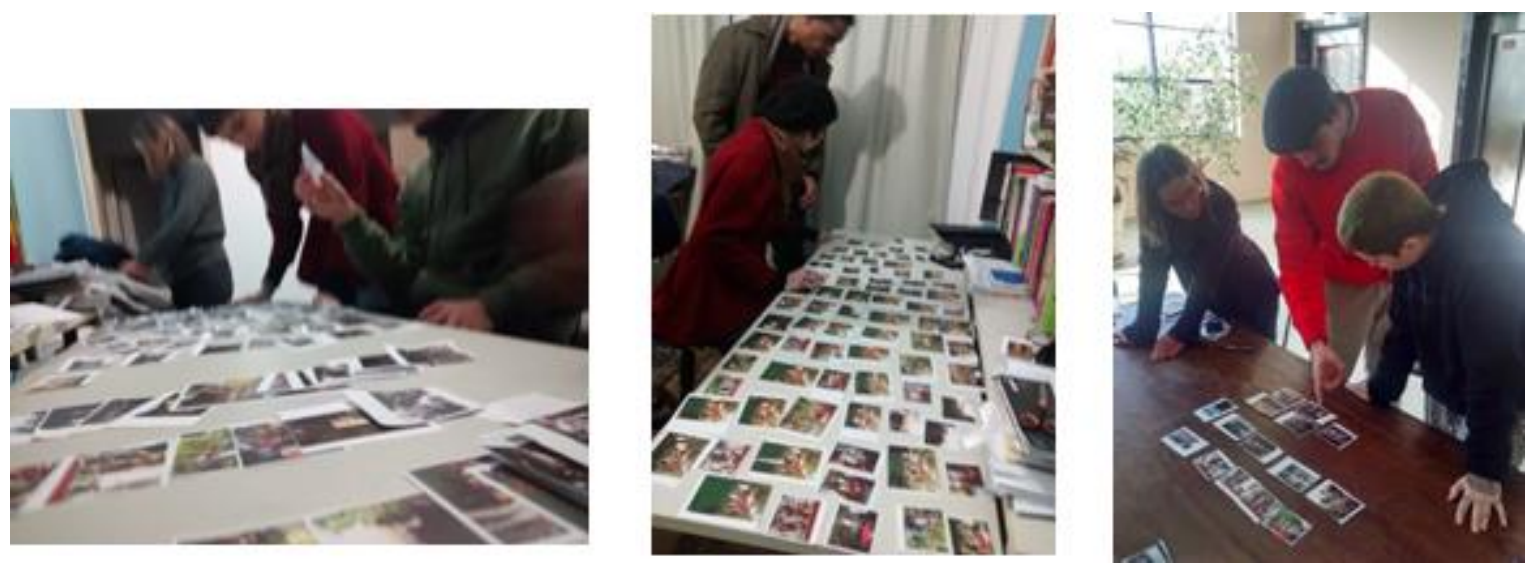

Momento da produção de coleções etnográficas sobre a Batalha do Mercado.

Fotos: Jose Luis Abalos Junior. 2016.

Após esse momento de análise das imagens o grupo decidiu trabalhar com três categorias que comporiam a estética juvenil da batalha do mercado e estariam dentro do projeto de núcleo de sentido: performance, estilos de vida e consumo. Estas categorias foram fruto de uma ação intencionada dos alunos de refletir sobre as imagens que eles produziram. Contudo, quando se aproximara o fim do período da disciplina e com isso a tarefa de construção de uma proposta de expografia na universidade, o grupo precisou tomar a decisão de eliminar algumas imagens, por conta de uma impossibilidade técnica referente às adequações para incluí-las na exposição. Ficou a lição de que fotografias capturadas a partir de aparelhos celular e smartphones têm uso em um trabalho no modelo bidimensional livresco, porém são limitadas quando se pretende materializá-las em 
dimensões físicas mais expressivas, o que inviabiliza o material para o propósito de uma exposição em termos fotográficos ${ }^{13}$.

Esse processo se mostrou inicialmente como uma frustração por parte dos alunos e do orientador do grupo. A realização do trabalho com coleções etnográficas, a construção de núcleos de sentido e de narrativas visuais precisavam ser repensadas através de outras possíveis imagens sobre a Batalha do Mercado. As impossibilidades técnicas levaram o grupo a pensar outras formas de apresentação desta expressão juvenil, mas também a repensar as práticas de ensino-aprendizagem (Eckert; Rocha, 2013) envolvidas durante todo o processo de captação de imagens e produção de um banco de conhecimento. Neste sentido, os problemas técnicos foram importantes para conduzir reflexões sobre novas visualidades possíveis de configuração visual do nosso objeto desejado.

Evidenciada esta ruptura, o grupo buscou imagens de um coletivo chamado "Núcleo de Fotografia Callejera", que realizou um trabalho de produção de imagens na Batalha do Mercado. O novo desafio que se colocava se dava em como utilizar antropologicamente imagens que não haviam sido produzidas com uma intencionalidade etnográfica. Um processo de categorização em eixos de sentido destas novas imagens foi o primeiro passo. Elementos como a estética da noite, as formas de sociabilidade e o consumo de diversas mercadorias lícitas e ilícitas estavam presentes. Logo, com interlocução consentida, nos apropriamos dessas imagens pensando novas formas de conceitualização e de exposição.

Como exemplo de elaboração de narrativas visuais, o núcleo de sentido "performance de jovens no espaço público" diz respeito a um significado partilhado entre os integrantes do grupo de trabalho de que essa manifestação comporia um cenário simbólico da estética da noite. Podemos encontrar no estruturalismo figurativo de Gilbert Durand (2002) o papel do "regime noturno" na produção de símbolos e de figurações no espaço público. Em contraposição à uma estética diurna, é na noite que muitos estilos de vida juvenis se expressam na cidade. A noite abriga um espaço fantástico no qual "a imaginação noturna é, assim, naturalmente levada da quietude da descida e da intimidade, que a taça simbolizava, à dramatização cíclica na qual se organiza um mito do retorno” [...] (Durand, 2002: 279). Se durante o dia prevalece a simbologia da separação destes coletivos

${ }^{13}$ Dependendo dos atributos técnicos do aparelho celular/smartphone (ou até mesmo uma câmera digital mais limitada), a resolução inferior das imagens não permite sua impressão em tamanho ideal para uma exposição fotográfica sem que não se perca consideravelmente a qualidade do material. 
de jovens, é na noite, espaço da proximidade, informalidade e ousadia, que se figuram estas formas de congregação juvenil.

O uso da ferramenta audiovisual e a construção de uma crônica etnográfica foi uma alternativa encontrada para reintroduzir as imagens de autoria do grupo de trabalho antes descartadas da parte fotográfica da exposição devido à impossibilidade técnica. Esse percurso do vídeo foi importante, pois os integrantes do grupo se mostravam saudosistas com as imagens por si produzidas e a narrativa videográfica foi uma forma de dar conta deste anseio. Portanto, com a ajuda da cineasta Thais Fernandes, foi elaborado um vídeo representativo das Batalhas de MCs, que foi exibido na exposição concomitante às fotos do grupo "Callejera" então pensadas expograficamente pelos alunos.
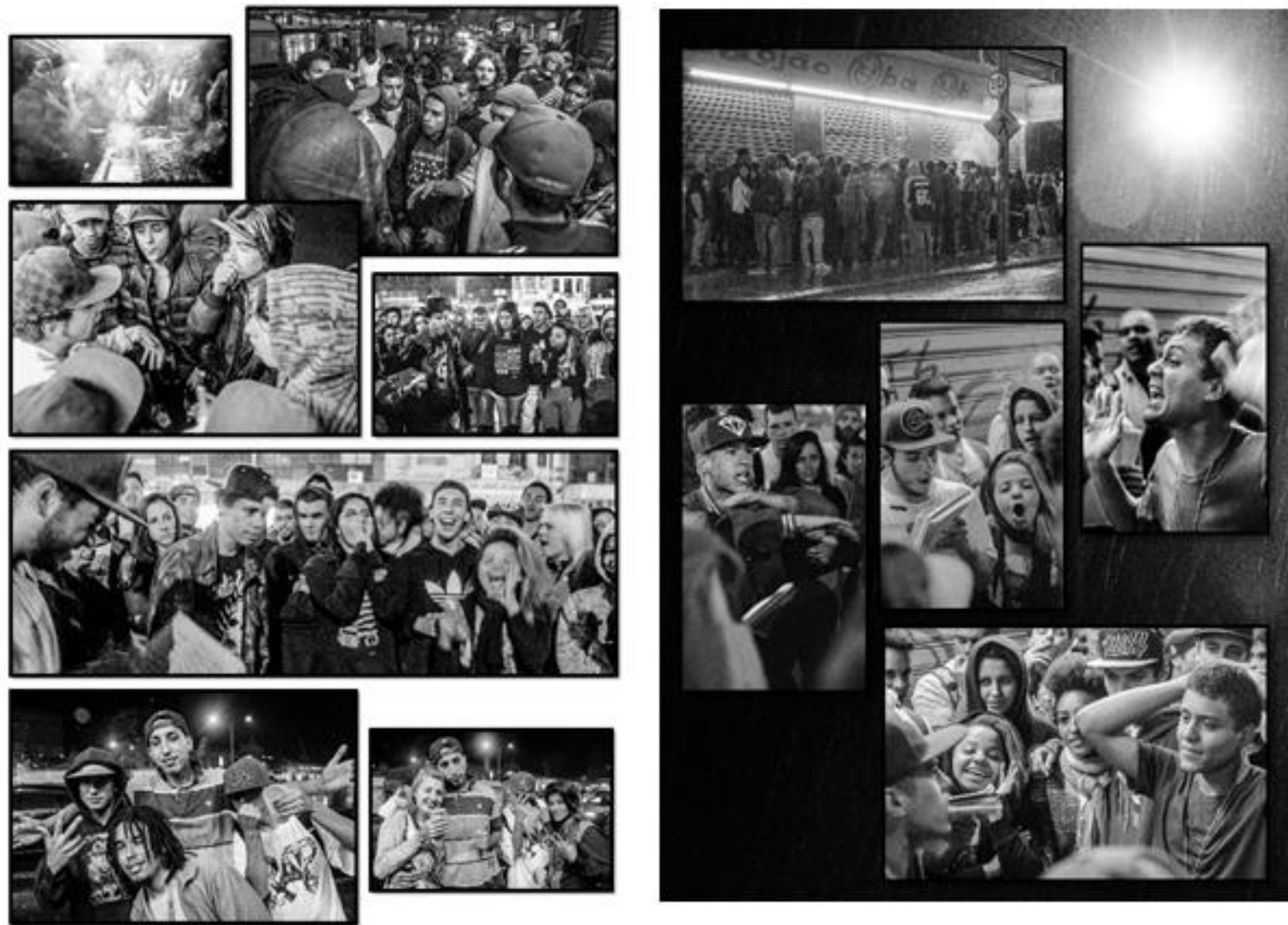

Os croquis de imagens sobre a Batalha do Mercado apresentados no projeto expográfico da disciplina. Imagens: Coletivo de Fotografia Callejera. Montagem: Felipe Rodrigues. 


\section{A imagética do skate enquanto projeto: relatos de um jovem skatista}

O trabalho intitulado “Pistas e 'Picos': Antropologia Visual e Skate em Porto Alegre", foi realizado por Ânderson Fragozo, Carmem Guardiola e Maurem Fronza, coordenados por Guillermo Gómez. O processo de definição do objeto de pesquisa integrou a metodologia própria de uma antropologia da e na cidade cidade: fez-se uso de uma “observação flutuante”, termo cunhado por Colette Pétonnet (2008) para definir uma caminhada fruto de um olhar que evita um a priori e se coloca aberto às surpresas da cidade. Contemplar a cidade através de seus imprevistos, ou através das "colagens de seus fragmentos de interação" como descrevem as antropólogas Ana Rocha e Cornelia Eckert em sua "etnografia de rua" (2013b: 25). Dessa forma, realizamos uma caminhada pelo centro histórico da cidade de Porto Alegre, interagindo com diferentes pessoas e grupos: pessoas em situação de rua no Viaduto Otávio Rocha; assistimos uma performance de dança nas ruas ao redor da praça da Matriz; visitamos brevemente a ocupação Lanceiros Negros, localizada em um prédio histórico entre as ruas Andrade Neves e General Câmara. Dentre essas diversas temáticas extremamente instigantes, escolhemos a prática do skate, viabilizando uma inserção e comprometimento ético que fosse condizente com o tempo de um trabalho para uma disciplina. Também nos chamava atenção a reapropriação dos espaços públicos urbanos realizada pelos jovens skatistas.

A partir de então, as saídas de campo se concentraram nos espaços onde reconhecemos a prática do skate, permitindo que realizássemos interações com os interlocutores. Transitamos, especialmente por dois territórios urbanos que, apesar de integrarem o "circuito" (Magnani, 2012) do skate em Porto Alegre, se diferenciavam bastante. O primeiro, a pista do IAPI, localizada entre os bairros Higienópolis e IAPI, representa um lugar projetado para andar de skate: a pista de skate significa tanto a “regularización”, “formalización” o "racionalización” (Márquez e Díaz, 2015: 145) da prática, como possibilita trajetos que ampliam a circulação dos jovens no meio urbano evitando sua "sedentarização nos bairros de origem” (Olic, 2008). Esta pista é um espaço aberto de cimento e possui diferentes obstáculos como corrimãos, escadas, rampas, bancos, etc. Se constitui enquanto um agregador de fluxos diversos e é palco de importantes 
campeonatos $^{14}$ que integram este "circuito jovem" (Magnani, 2005).

O segundo local que pesquisamos é a Praça da Matriz (Praça Marechal Deodoro), que integra o patrimônio histórico da cidade. Identificou-se, neste caso, um uso cotidiano para além de sua forma planejada, um "espaço praticado" nas palavras de Michel de Certeau (1994). A arquitetura das escadas que levam ao monumento em homenagem a Júlio de Castilhos se configura como um bom "pico", isto é, um local que agrega uma série de características que o torna adequada a prática do skate ${ }^{15}$.

Foram nestes espaços que centramos a abordagem de campo e interagimos com diversos jovens, do sexo masculino e de faixa etária de 13 a 20 anos. Como nos propúnhamos a realizar uma etnografia de rua "com a câmera" na mão (Rocha \& Eckert, 2013b), isto é, buscando uma interface da Antropologia Urbana com a Antropologia Visual e tendo a imagem como forma de restituição (Rocha \& Eckert, 2014), lançamo-nos a negociar a produção imagética com os sujeitos de pesquisa, por meio de interações etnográficas. Destes contatos, o primeiro elemento que notamos, enquanto estudantes iniciantes no uso dos equipamentos técnicos, era que os próprios interlocutores faziam uso das imagens fílmicas e fotográficas - com bem mais propriedade do que nós, para dizer com franqueza - e que essas imagens estavam ligadas aos projetos de vida daqueles sujeitos, assim como do skate enquanto "modo de vida" (Velho, 2013).

Por essa razão, nossas narrativas incorporam o "backstage" desta confecção imagética dos skatistas. Foi interagindo com estes jovens, que praticavam este esporte e compartilhavam imagens de si e dos outros, que começamos a negociar e nos aproximar de uma estética do olhar do skatista sobre si, o outro e a cidade. É claro que estamos cientes de que qualquer modelo etnográfico se apresenta enquanto uma "simplificação grosseira" (Fonseca, 1998: 76) daquilo observado e vivenciado.

\footnotetext{
${ }^{14}$ Como a final do Red Bull Skate Arcade, o Matriz Skate Pro, etc.

${ }^{15}$ Giancarlo Machado (2011: 114) define três "características ideais" que definem um bom "pico": "chão de ida", lugar que o skatista toma impulso em direção ao obstáculo, deve ser liso e possibilitar um fácil deslocamento; "o obstáculo", os equipamentos urbanos nos quais o skatista realiza as manobras, podem ser escadas corrimãos, etc e, por fim, "o chão da volta”, o local onde o skatista aterrissará após a manobra.
} 

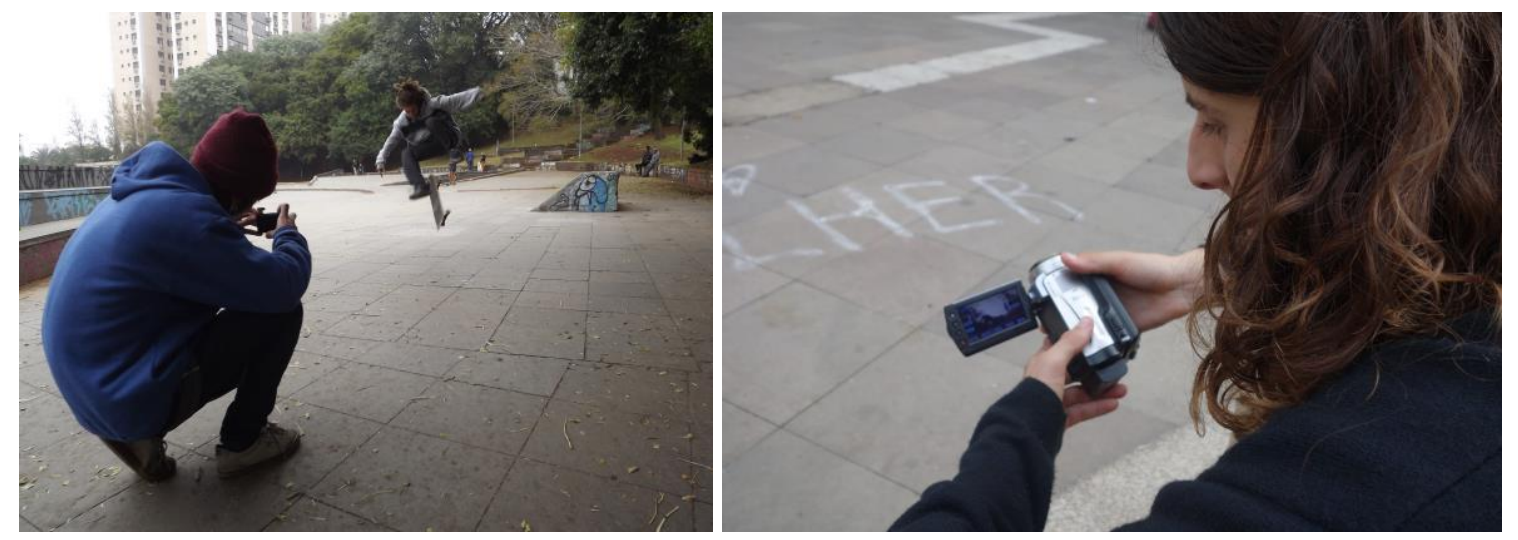

Fotos: Maurem Fronza (esq.) e Guillermo Gómez (dir.). 2016.

Foi assim, produzindo imagens, que encontramos Ryan Edhuardo, 16 anos, na pista do IAPI, no dia quatorze de maio de 2016. Utilizando seu celular, com a tela rachada devido às quedas, Ryan filmava seu amigo Robson "Piloto", de 13 anos. Ryan utilizava uma lente "olho de peixe" (fisheye), que produzia um efeito de destaque em seus vídeos e fotografias. O rapaz oportunizou que utilizássemos esse equipamento técnico em nossos próprios celulares. Robson e Ryan escolheram o obstáculo, uma escada com três largos degraus, o primeiro se dirigindo a ela para saltá-la, enquanto Ryan auxiliava na produção das fotografias, destacando a importância das fotos em sequência para a captação dos movimentos e da manobra executada pelo mais jovem.

Ryan nasceu em Viamão e mudou-se para Alvorada - ambos municípios que compõem a região metropolitana de Porto Alegre e é lá que mora desde seus nove anos e, depois que sua irmã se casou, reside apenas com sua mãe. Essa mudança foi importante para Ryan, saindo de uma rua "que todo mundo jogava bola", para Alvorada onde "todo mundo andava de skate". Com um skate montado de peças usadas dos "guris mais velhos" de sua rua, começou a andar e praticar. Aos 12 anos a maioria de seus amigos havia parado de andar de skate, muito influenciados pelo funk: "queriam ser funkeiros e essas coisas, mas eu decidi que não iria parar só porque todo mundo tinha parado". Depois que descobriu a "pista local" de Alvorada, percebeu que existia um mundo mais amplo dentro do skate, que se expandiu mais ainda quando conheceu pela primeira vez o IAPI: 
RYAN: “A primeira vez que vim pro IAPI, tinha 12 anos, daí só vim uma vez né? Eu nossa meu nem sabia que tinha pista desse tamanho, que nossa pista lá [em Alvorada] é pequena. Daí comecei a ver vídeo no youtube, nao tinha internet em casa, fui na casa de um amigo. [Disse pra ele] eu fui nesse lugar aí [IAPI], quem é esse cara ai? -'É o Luan de Oliveira, skatista profissional, lá de Porto Alegre." Ele, com a nossa idade, já tinha patrocínio da Flip, que é uma marca bem boa. E eu: bah, que tri, imagina eu assim. Daí eu imaginei que comigo seria quase impossível porque sou de Alvorada, sabe? Ele andou bem, teve esse futuro por causa daqui, dos obstáculos, ele pode aprender a andar em banco, a andar em corrimão...” (Diálogo realizado em 14 de maio de 2016)

Este relato evidencia outros aspectos importantes deste campo, deslocamento dos jovens pela área metropolitana de Porto Alegre, a pista do IAPI representando uma alternativa de qualificação no esporte, por apresentar uma maior variedade de obstáculos e possibilidades de praticar. Também surgem as figuras de referência (os atletas profissionais), que estabelecem verossimilhança (Magnani, 2003) com os jovens, e fundamentam a idealização de um projeto: "quero ser assim”.

No momento da despedida e da troca de contatos, uma surpresa: é Ryan quem administrava as mídias sociais de Robson, divulgando as manobras do mais jovem. "Ele já é patrocinado e é importante que apareçam vídeos dele com as marcas [que o patrocinam], então eu ajudo", explicou-nos Ryan. A produção e circulação de imagens de si e dos outros são intrínsecas aos projetos de vida destes jovens skatistas, possibilitando tanto satisfação pessoal como mobilidade social ("comecei a andar pensando na minha mãe, ta ligado? Pensando no meu futuro" - Robson, 13 anos maio de 2016), dialogam com marcas e campeonatos. 

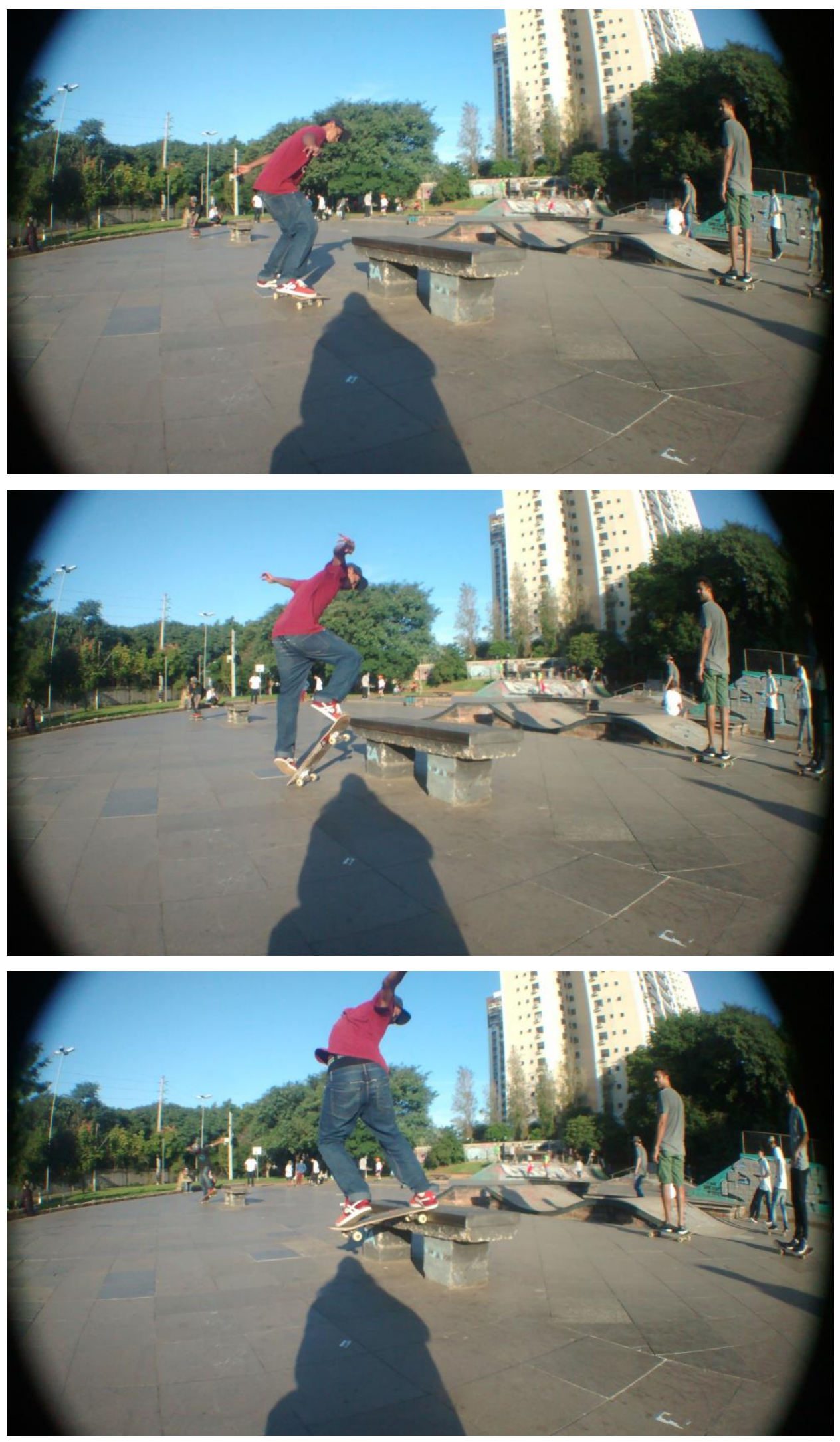

Ryan - Sequência com lente olho de peixe. Fotos de Guillermo Gómez. 2016. 


\section{Skatista profissional ou profissional do skate?}

Em razão de termos mantido contato com Ryan, que atuou, através dos contatos pela internet $^{16}$, como um mediador na seleção de fotos para a exposição, pudemos retornar os diálogos, nos meses de abril e maio de 2017. Neste segundo momento, passado um ano de nossa primeira interação, apresentou-se um Ryan diferente, enquanto personagem de sua “identidade narrativa”. Hoje com 17 anos, o jovem encara novos dilemas, realocando seu lazer favorito em sua rotina: "jogo basquete a pouco menos de um ano e nos dias de semana ando de skate, porque ainda não consegui emprego". Ele conta um pouco das novas perspectivas: “ dia 5 de junho [2017] vou começar a estagiar na Unimed, como auxiliar administrativo. Eu vou ser o que ajuda o administrador da empresa e vou aprendendo pra um dia poder substituir ele. Vou ganhar remuneração”. Quando questionado a respeito do skate, ele afirmou: "Eu não tenho mais chances de seguir uma carreira como skatista profissional, talvez como empresário no ramo do skate, tipo criar uma marca ou abrir uma loja”, “eu posso não ser skatista profissional, mas já sou um profissional do skate"17.

Quando Guillermo ressaltou essa mudança, dizendo: “já faz quase um ano que nos falamos e em 2016 tinhas outra perspectiva em relação a um projeto de vida vinculado ao skate, concorda?" Ryan respondeu: "sim, os pensamentos correm muito rápido". A efemeridade dos projetos (Velho, 1994) juvenis se defronta com um campo de possibilidades que a todo tempo se reconfigura, consequentemente, e no passo de constantes rupturas são reimaginados e reelaborados os projetos (Schutz, 1979). Frente a essa "ação corrosiva do tempo" (Rocha e Eckert, 2013a: 32) também se identifica um ato de "duração", um esforço (Bachelard, 1988) de manutenção de algo que lhe dá prazer em experienciar, assim como de sua própria identidade narrativa.

\footnotetext{
${ }^{16}$ Como indica Ricardo Campos(2012), uma série de pesquisadores das culturas juvenis enfatizam uma alimentação mútua entre os campos online e offline (Campos, 2012: 556). Devido a dificuldade de deslocamento do Ryan até o centro da cidade, foi através do Facebook que mantivemos contato, assim como realizamos esta segunda conversa.

${ }^{17}$ Essa parece ser uma expressão corrente dentre os skatistas, como apresenta Machado (2011), ao analisar as trajetórias dos videomakers, sujeitos que não detinham um "nível de skate" (idem: 194) que consideravam correspondente para viver da prática, dedicavam-se a outras funções, como a produção de vídeos, sempre relacionado ao skate, inserindo-se no que chamam de "trabalhar com o que dá prazer (idem, ibidem).
} 


\section{Democratizar a Esquina, conquistar a cidade: A Feira do Hip Hop e as poéticas da periferia}

A experiência de aproximação junto à Feira do Hip Hop surgiu para o grupo de trabalho ${ }^{18}$ em meio a uma "caminhada à deriva" por entre as ruas do Centro Histórico de Porto Alegre. Deriva que não implicou em aleatoriedade, pois conduzida pelo intuito do exercício etnográfico proposto na disciplina de Antropologia Visual, a partir do qual buscava-se abordar um objeto empírico pertinente para reflexões em torno do tema das “intervenções urbanas". Definiu-se então para uma manhã de sábado o percurso a ser realizado ao longo da Rua dos Andradas, onde se apresentam diariamente vários artistas de rua: artesãos, estátuas-vivas, músicos, pintores e escultores, que dividem espaço com indígenas kaingang (que ali desenvolvem atividades variadas, como a venda de produtos artesanais, ervas para chá, itens manufaturados), hippies, trabalhadores do comércio informal e com o trânsito profuso de pessoas que é comum às zonas centrais e comerciais dos centros urbanos. Munidos de câmera na mão, gravador de som e diário de campo seguindo as orientações de uma etnografia de rua (Rocha e Eckert, 2003; 2013b) - os membros de nosso grupo se lançaram neste cenário composto por um variado leque de possibilidades interessantes à atenção etnográfica em diversos aspectos, porém mais ou menos viáveis para uma tentativa de interlocução.

Os ritmos de uma batida musical tomavam corpo e começavam a ressoar com mais força à medida em que a equipe se aproximava da Esquina Democrática ${ }^{19}$. Bem no centro do cruzamento, um grupo de pessoas organizava a montagem de tendas, caixas de som e aparelhos de discotecagem, estandes para a venda de cd's, roupas e artesanato. Um tapete logo viria a ser colocado à frente das tendas, improvisando uma pista de dança a céu aberto, que não se limitava ao manto quadriculado e se estendia ao longo do círculo imaginado que passara a ocupar o passeio intensamente trafegado. Em poucos minutos, a Feira do Hip Hop daria início à sua programação.

\footnotetext{
${ }^{18}$ Grupo composto pelos alunos Javier Calixto, José Thiago Ruhee, Larissa Signor, Nara Rech e Patrick Gomes, orientado pelo estagiário e pesquisador associado ao Navisual Manoel Rocha.

${ }^{19}$ Lugar historicamente reconhecido como espaço de resistência das populações negras de Porto Alegre, localiza-se no cruzamento da Rua dos Andradas com a Avenida Borges de Medeiros.
} 
O primeiro contato, em forma de apresentação, aconteceu de forma breve com um dos jovens que ali estava: "Somos da UFRGS e estamos fazendo uma pesquisa sobre arte de rua e queríamos sua permissão para circular pelo local, tirarmos algumas fotografias e falarmos com eles" (referindo-se ao grande grupo de jovens ali presentes). A recepção positiva deu ao grupo a certeza de que ali se encontrava uma possibilidade interessante de interlocução para o exercício. Rapidamente nos apontaram para a área das tendas, indicando um dos organizadores do evento que poderia conversar conosco e nos esclarecer melhor sobre o que se passava ali: "Fala com ele, o Fabio. Ele vai te informar melhor".

Fabio nos atendeu prontamente. Afastamo-nos das caixas de som para que a conversa fluísse de forma mais adequada, quando então nos apresentamos a ele, situamos o motivo acadêmico de nossa aproximação e solicitamos mais uma vez a permissão para o uso da câmera fotográfica e gravador de som para o registro de sua fala. Conhecido também como "Seguidor F.", contou-nos de forma sucinta sobre sua trajetória no Hip Hop, sua atuação como MC, bem como os trabalhos que desenvolve com crianças e adolescentes de periferia. Apresentou o que era a Feira do Hip Hop, aproveitando para indicar os demais idealizadores/organizadores do evento.

\section{Entre o agonístico e o lúdico: poetizando o urbano pela estética da disputa e do jogo}

A Feira de Hip-Hop é um evento mensal que reúne pessoas e coletivos oriundos de bairros da periferia de Porto Alegre vinculados à "Cultura do Hip Hop". Ocorre preferencialmente no primeiro sábado de cada mês, na Esquina Democrática, cruzamento entre a Rua dos Andradas e Avenida Borges de Medeiros, no Centro Histórico da capital gaúcha. Apropriando-se de um espaço histórico para a cultura negra da cidade, um dos objetivos da Feira é promover e divulgar a "cultura da periferia", neste caso, incentivar o trabalho dos artistas locais através dos quatro elementos fundamentais do Hip Hop: a expressão da dança conduzida pelos B-Boys, a performance dos DJs, a fala que ecoa pela voz dos mestres de cerimônia (MCs), e as cores que se imprimem na cidade pelo Graffiti. Como defendem seus organizadores, o evento se apresenta enquanto via para o movimento periferia-centro, onde a "cultura da periferia" pode se afirmar no coração da cidade. A Feira possibilita também a interação entre pessoas com as mais diversas trajetórias de vida em 
um espaço marcado pela dimensão lúdica que permeia jogos e disputas inseridos nos quatro elementos do Hip Hop.

No decorrer de quatro saídas de campo, nosso grupo desenvolveu uma interlocução proveitosa que possibilitou, inclusive, a mediação entre o coletivo de artistas e a universidade, culminando na participação da Feira de Hip Hop no evento "UFRGS Portas Abertas" de 2016. O material etnográfico produzido ao longo do exercício de pesquisa, perpassa centenas de fotografias dos inúmeros personagens encontrados e entrevistas em áudio e vídeo. Dentre nossos interlocutores menciono aqui Negra Jaque, Kanhanga e Mário Marques, figuras de destaque na cena do Hip Hop na capital e com as quais tivemos oportunidade de estabelecer uma interlocução mais prolongada.

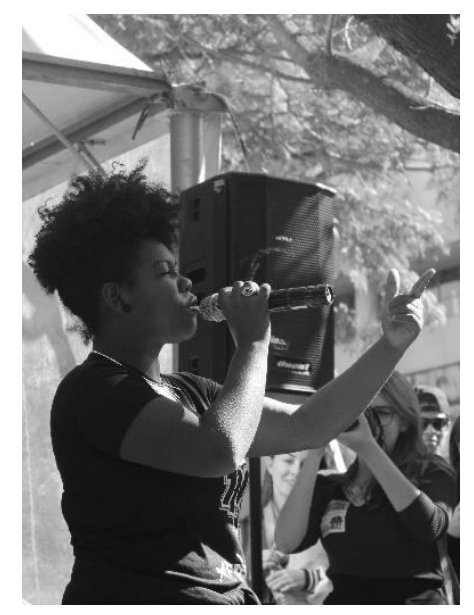

Negra Jaque. Foto: José Thiago Ruhee. 2016.

Negra Jaque nos conta que é ativista da cultura do Hip Hop desde 2007. Está entre os organizadores da feira: rapper, produtora cultural e com formação em Educação Popular, ela é oriunda do Morro da Cruz, periferia localizada na zona leste de Porto Alegre. Sua fala é pertinente no sentido de lançar o olhar sobre e valorizar o protagonismo das mulheres na trajetória do Hip Hop.

De nacionalidade angolana, "Narrador Kanhanga" é também rapper e um dos idealizadores da Feira do Hip Hop em seu formato atual. O primeiro contato com a cultura do hip hop é ainda na infância, em Angola. Veio para o Brasil em 2005, após receber uma bolsa de estudos no curso de Administração de Negócios Internacionais. Estabelecendo-se em Porto Alegre, aproximou-se de grupos locais passando a desenvolver seu trabalho em 
solo brasileiro.

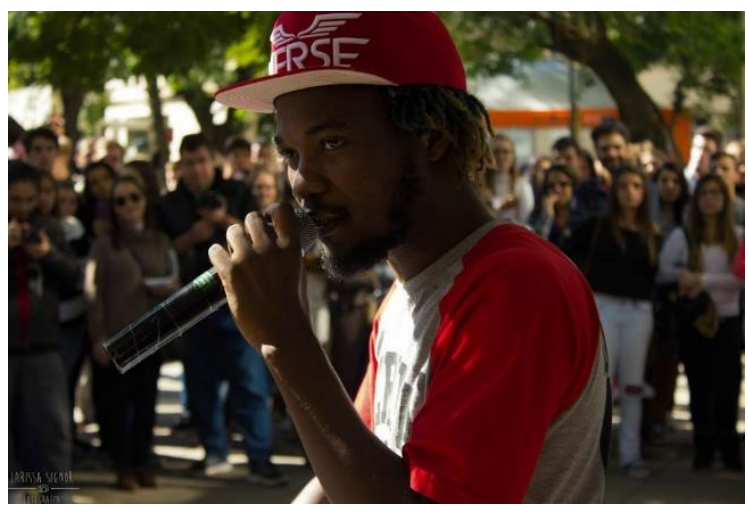

Narrador Kanhanga. Foto: Larissa Signor. 2016.

Morador do bairro Mário Quintana, localizado entre a zona norte e o extremo leste de Porto Alegre, Mário Marques vivencia a cultura do Hip Hop desde sua infância. Seu pai, Renato Marques, é figura importante para o movimento da Black Music na capital gaúcha, e vivenciou a geração que deu início ao que se configuraria mais tarde como o cenário do Hip Hop em Porto Alegre. A Feira, que em sua versão contemporânea é organizada há três anos é, na verdade, uma versão atualizada do evento idealizado e organizado anteriormente por ativistas do hip hop desde a década de 1980 na Esquina Democrática ${ }^{20}$, que é palco também de uma variedade de outros eventos promovidos por diversos coletivos vinculados ao movimento e cultura negra em Porto Alegre. Logo, é herdeira de várias outras expressões da presença negra no Rio Grande do Sul e que ao longo dos anos se apropriaram do espaço da Esquina Democrática.

\footnotetext{
${ }^{20}$ Vale frisar que o espaço é regularmente palco de outros eventos promovidos por diversos coletivos vinculados ao movimento e cultura negra em Porto Alegre.
} 


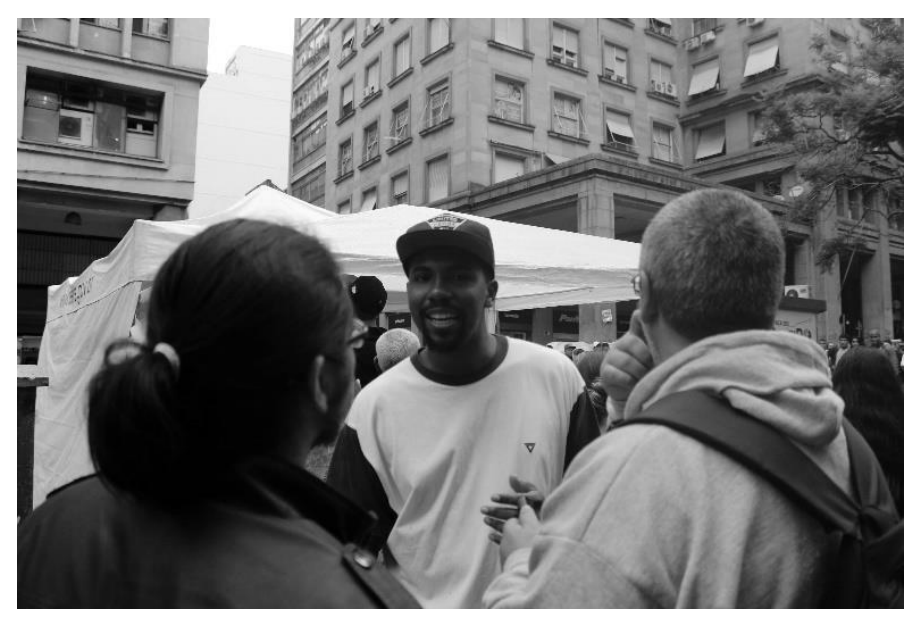

Manoel Rocha (esq.), Mário Marques (centro) e Javier Calixto (dir.). Foto: José Thiago Ruhee. 2016.

A atuação destes três personagens vai além da Feira realizada na Esquina Democrática. O hip hop é ferramenta através da qual desenvolvem uma série de projetos sociais em seus bairros de origem e nas periferias de Porto Alegre. Destacamos para este trabalho um fragmento composto de trechos da narrativa biográfica de Mário Marques:

MÁRIO MARQUES: Cara, eu nasci dentro do Hip Hop. Meu pai é um dos idealizadores aqui da Feira, em 1976. Meu pai é ativista do movimento, e dentro desse movimento eu sempre tava inserido, querendo ou não, vendo meu pai... gostava. Mas meu primeiro contato com o Hip Hop foi entre nove e dez anos, que eu tentei ser MC, tentei ser BBoy, tentei ser grafiteiro, mas onde eu me identifiquei mesmo foi o DJ, né cara. Eu tentei todos os elementos e o elemento DJ foi onde me chamou atenção, onde eu me empenhei. Tipo, comecei a estudar DJ. Mesmo os equipamentos sendo muito caros... meu pai sempre dando auxílio... consegui... sempre acabava indo em festa, olhando os cara ali, aprendendo e meio que autodidata [...] A partir do momento que eu vi que aquilo ali não era uma brincadeira, era uma profissão, eu acabei assumindo mesmo a função e tô aí a uns 11 anos, posso dizer, na área do DJ. Já toquei dentro da capital, fora da capital, fora do país, então... consegui fazer um intercâmbio na França eu fiz dois cursos de $\mathrm{Dj}$, dj renomado do mundo inteiro. E é onde eu continuo lutando, a minha ideia é essa... todo esse conhecimento que eu tive fora do estado e fora do país eu tento levar pra comunidade através do projeto que a gente desenvolve lá na instituição que é a ONGSUVE, que é a educação do modo não-formal.

$[\ldots]$

Eu posso dizer que o Hip Hop atua em diversos segmentos. Tanto no movimento social, no lance de integrar uma comunidade periférica dentro dum contexto de uma cultura, tanto no lance de participar da economia solidária, que nem aqui a gente traz o cd das pessoas independentes, que acabam criando, fazendo seu próprio trabalho, fazendo uma economia solidária nisso. Tem a marca da rapaziada da King ali, marca própria que vende, que faz um trabalho. Tem o artesanato das gurias aí. E acaba mexendo com o social, com o financeiro e daí, tipo, é... juntar, só vai agregando valores, na real, à cultura [...] E isso a gente faz através de eventos de rua, palestra, curso. Que é apresentar cultura e fomentar ela. Como é uma cultura de periferia e é muito forte dentro da comunidade, a ideia é descentralizar isso aí pro centro, mostrar que na periferia tem coisas boas e tirar aquele rótulo de marginalidade, "a periferia tem isso, isso e isso", e 
mostrar todo o outro lado".

$[\ldots]$

Eu não me contentei de ficar na minha comunidade, de ter aquela visão de mundo, só aquilo ali. Eu sou formado em Análise de desenvolvimento de sistemas. Conheço 11 países através de projetos do governo federal, estadual e municipal. E mostrando meu lado periférico, meu lado de periferia.

$[\ldots]$

O Hip Hop pra muita gente é um estilo musical, mas pra gente que segue é uma cultura. A cultura de periferia... que mudou a minha vida, como deve ter mudado a maioria da rapaziada que faz o rap, que faz o hip hop dentro dos quatro elementos, os pilares: o BBoy, o Graffiti, o DJ e o MC.

Mário nos narra um Hip Hop que se afirma na música, na dança, na maneira de vestir, na relação com as tecnologias e as potencialidades que estas permitem, no praticar a cidade e seus espaços. É pelo Hip Hop e através dele que o DJ imprime sua trajetória nas paisagens urbana, que imprimem também suas marcas na vida do jovem, em seus percursos de materialização de projetos pessoais que dizem respeito à sua formação profissional, acadêmica, artística, política, que se estendem também ao longo de projetos coletivos ligados a realidade da população de periferia: um emaranhado de trajetos por meio dos quais vibram sonhos particulares e anseios de transformação da cidade e da vida de seus habitantes. O Hip Hop se constitui enquanto uma forma de conhecimento que remete à ordem do sensível e que se imprime criativamente no ato mesmo de viver o urbano.

Por meio da narrativa de Mário e do trabalho de observação e acompanhamento da experiência de realização da Feira, adentramos na dimensão sensível que perpassa as quatro expressões pilares do Hip Hop enunciadas através das rítmicas que conduzem os corpos ali envolvidos. O conhecimento que se constitui como "quinto elemento" emerge dos demais e através destes, ao mesmo tempo que os impulsiona e os mobiliza.

Esta dimensão sensível vibra na potencialidade da Feira de Hip Hop em agregar uma diversidade de pessoas das mais diferentes trajetórias em um espaço público de intenso fluxo. As tendas começam a ser montada por volta do horário do almoço, em algumas ocasiões mais cedo, outras mais tarde. Equipamentos de som, venda de cds, artesanato, roupas. Entre $13 \mathrm{~h}$ e $14 \mathrm{~h}$ o som já começa a atrair o público que se reúne em volta, formando um grande círculo. $\mathrm{O}$ tapete de dança estendido em frente à tenda sugere uma pista de dança, que antes de estabelecer uma fronteira em relação à plateia, transmite o convite para participar do espetáculo, reforçado continuamente pelos mestres de cerimônia. Aos poucos se vê a aproximação dos transeuntes saindo do trabalho, os que estariam 
fazendo compras ou a passeio, pessoas em situação de rua que se encontram nos arredores: todos bem-vindos e convidados a fazer parte da dança, a cantar seus versos, sua poesia, divulgar seus trabalhos, se divertir. O passeio da Esquina Democrática, este lugar praticado (Certeau, 1994) que é palco de diferentes "artes de fazer" do cotidiano, transforma-se poeticamente por meio dos quatro elementos do hip hop.

$\mathrm{O}$ ritmo dos gestos e dos movimentos se enuncia através dos corpos e pelos corpos. O jogo lúdico da disputa se vê, por exemplo, na performance dos B-Boys: cada um apresentando passos diferenciados, técnicas diversificadas, agregando diferentes estilos. A dança pode seguir de diferentes formas: ora, todos dançam livremente e simultaneamente; ora, um dos dançarinos é o centro das atenções por alguns segundos, para então passar a vez para outro, transição que se faz geralmente através de um gesto provocativo que convida/desafia o próximo a dançar, a "fazer melhor". O caráter agonístico se enuncia também no decorrer do evento através das insinuações e brincadeiras feitas entre os mestres de cerimônia: um gesto feito com o microfone, na poética de seus versos, na astúcia do improviso e da rima.

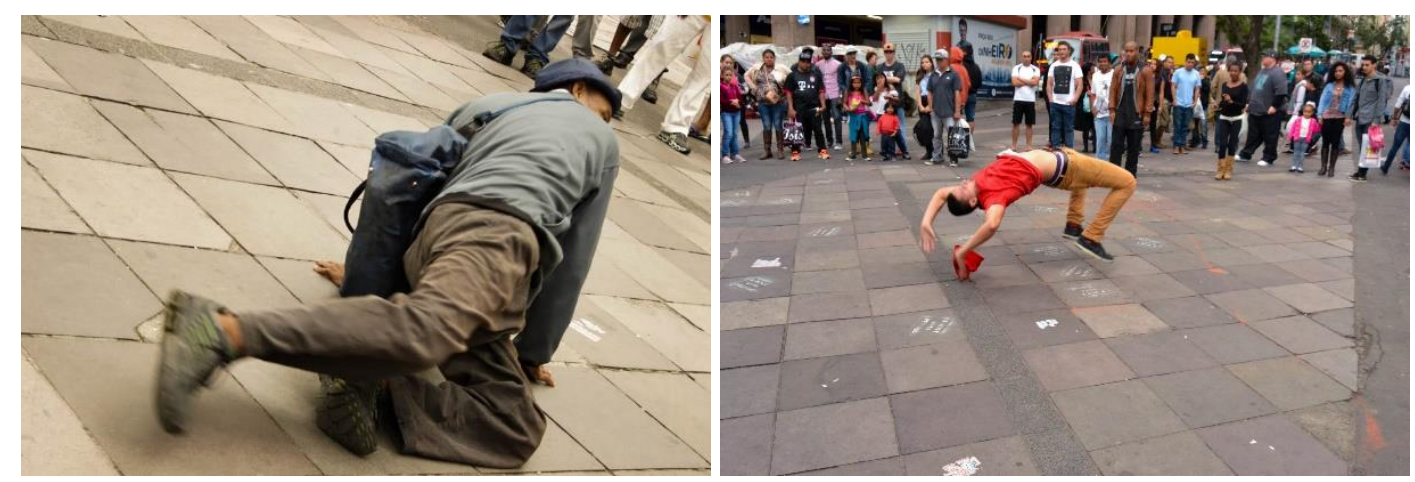




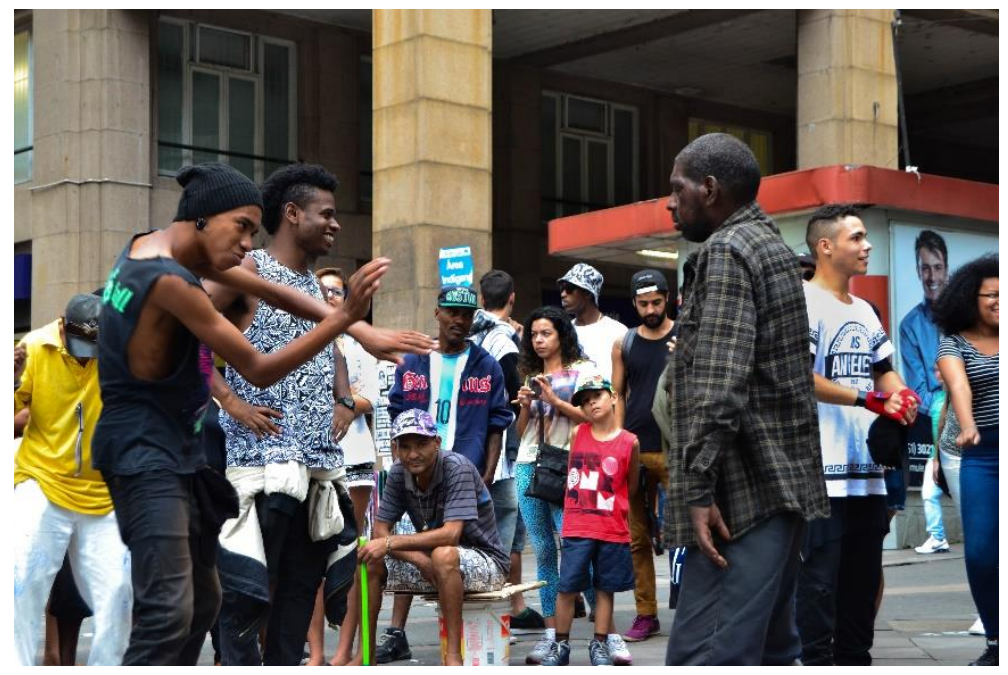

Feira do Hip Hop na Esquina Democrática. Fotos: Larissa Signor (esq.)/ Javier Calixto (dir. e abaixo).

A Feira do Hip Hop conforma um espaço sensível no qual jovens de diferentes áreas periféricas de Porto Alegre estetizam a cidade por meio dos quatro elementos do hip hop. É por meio destas formas sensíveis (Sansot, 1983; 1996; Ledrut, 1984; Rocha, 1995) de praticar, conhecer e transformar a urbe que estes sujeitos se apropriam do espaço e fabricam criativamente a rua, ao mesmo tempo que enunciam poeticamente seus corpos e seu direito à cidade no impulso mesmo de vivê-la.

O entrelaçamento entre os aspectos agonísticos e lúdicos nos quatro elementos do hip hop potencializa a capacidade do movimento de agregar diferentes trajetórias, práticas e perspectivas sem, contudo, homogeneizá-las num discurso que se proponha como única via. A Feira do Hip Hop é um espaço onde são colocadas em jogo diferentes tensões, tais como as fronteiras entre centro e periferia e o acesso desigual às políticas da cidade e aos direitos de seus habitantes. Ou ainda o enfrentamento das desigualdades de gênero, movido pelo cada vez maior número de artistas mulheres no contexto interno do hip hop (cenário que até recentemente era quase que exclusivamente masculino).

O Hip Hop ultrapassa o papel de produzir uma voz unitária ou uma representatividade "essencialmente autêntica" da periferia: é por conseguir reconhecer e valorizar a pluralidade de formas de experienciar os cotidianos da urbe que o movimento consegue impulsionar arte, política, conhecimento, cultura. Ao invés de estabelecer um mecanismo de "demarcação" da diferença, é por meio de uma estética agonística e lúdica materializada na Feira do Hip Hop que estes jovens artistas, ativistas, intelectuais colocam 
a diferença em debate, em jogo. Um espaço em que a juventude da periferia se apresenta em suas contradições, controvérsias, em disputa. A Feira do Hip Hop se constitui enquanto um espaço criativo de não-definição, resistência e constante afirmação, estetizando a diferença por meio das formas sensíveis de viver o urbano.

\section{Considerações finais}

Os diferentes relatos apresentados ao longo deste artigo percorrem um conjunto intrincado de etapas do fazer antropológico, que foi permeado por experiências de pesquisas direcionadas para a realização de etnografias visuais. O percurso revelou um denso processo de ensino-aprendizagem que tem início na discussão e elaboração de um programa de disciplina dentro do âmbito das atividades do Navisual. O que nos conduziu ao acompanhamento e desenvolvimento de aulas, tendo como objetivo sensibilizar os alunos para um diversificado leque de opções teórico-metodológicas pertinentes ao campo da Antropologia Visual. Além disso, a experiência possibilitou aos discentes o contato com um variado arcabouço técnico em fotografia, produção audiovisual, sonora e artística possibilitado pela participação especial de profissionais de diferentes áreas ao longo do semestre, contribuindo com seminários e aulas expositivas acerca de suas produções, trajetórias e formações.

Uma das experiências de grande relevância enquanto prática de ensinoaprendizagem e que aqui descrevemos ao longo do trabalho foi o exercício etnográfico realizado pelos grupos de trabalho. A oportunidade de vivenciar a prática de orientação dos alunos - atividade pertinente também à função implicada pelo estágio docente (condição através da qual se inseriram os três autores) - somou-se à experiência de desenvolver trabalho de campo coletivamente com os estudantes entre os grupos e coletivos de jovens em Porto Alegre, por sua vez orientada por uma perspectiva temática em comum. As interações e interlocuções junto aos parceiros de pesquisa, como também entre orientadores-estudantes e/ou orientadores-orientadores, forneceram um material diversificado a partir do qual buscamos problematizar questões pertinentes ao fazer antropológico e o trabalho com imagens em contextos etnográficos. 
A construção de uma expografia compartilhada apresenta-se também como importante processo de restituição da produção de conhecimento antropológico. O resultado final de uma disciplina acadêmica e, sobretudo, dos exercícios etnográficos desenvolvidos por alunos e orientadores não se resumiu a um instrumento avaliativo inserido no modelo de uma monografia textual de "fim de semestre". A exposição que seguiu a experiência "na rua" e em sala de aula conforma mais que uma ferramenta de "retorno" aos grupos e coletivos que consentiram o diálogo e se dispuseram a narrar diferentes formas de viver a cidade.

A primeira ruptura criativa que podemos sugerir refere-se ao âmbito do fazer antropológico e diz respeito às possibilidades narrativas outras que o trabalho com imagens permite. A questão aqui não é propor um leque de estratégias retóricas alternativas à linguagem canônica do texto escrito. De um lado, é um esforço teórico e epistemológico no sentido de defender um estatuto ontológico da imagem no seio da produção de conhecimento antropológico em contraposição ao "triunfo do iconoclasmo" (Durand, 1995) que se consolida no pensamento moderno ocidental. Do outro, possibilita uma ruptura que adentra uma dimensão política, na medida em que amplia o alcance e acessibilidade da produção antropológica considerando os novos horizontes para sua materialização e circulação. Em termos concretos, esta segunda ruptura criativa diz respeito às "aberturas" mesmo que sutis - que a expografia pode provocar em um espaço institucional: um cotidiano habitualmente marcado por normas, trâmites burocráticos, práticas institucionais passou então a conviver com a presença de sujeitos convidados a compartilhar daquele espaço e narrar ali suas histórias com e através das imagens. 


\section{Referências}

BACHELARD, G. 1978. A filosofia do não; O novo espírito científico; A poética do espaço. Coleção Os Pensadores. São Paulo: Abril Cultural. 355p.

BACHELARD, Gaston. A dialética da duração SP, Ática, 1988.

BACHELARD, Gaston. A intuição do instante. 2 ed.- Campinas, SP : Verus Editora, 2010.

BENJAMIN, W. 1996. O Narrador: Considerações sobre a obra de Nikolai Leskov, in Magia e Técnica, Arte e Política. Ensaios sobre Literatura e História da Cultura, pp 197-221.São Paulo: Brasiliense.

BENJAMIN, W. 2000. Charles Baudelaire - um lírico no auge do capitalismo. São Paulo: Brasiliense. 271p.

CAMPOS, Ricardo. A pixelização dos muros: graffiti urbano, tecnologias digitais e cultura visual contemporânea. Porto Alegre, v. 19, n. 2, pp. 543-566, maio/agosto 2012

CERTEAU, Michel de. A invenção do Cotidiano: artes de fazer. Rio de Janeiro: Petrópolis, 1994.

DIAZ, Raul. Personaje e identidad narrativa: una aproximación metodológica. Revista Horizontes Antropológicos, número 12, ano 1999.

DURAND, Gilbert. A fé do Sapateiro. Brasília: Editora Universidade de Brasília, 1995. 233p.

DURAND, Gilbert. A imaginação simbólica. Lisboa, Perspectiva, 1980.

DURAND, Gilbert. As estruturas antropológicas do imaginário: introdução à arquetipologia geral. 3. Ed. São Paulo: Martins Fontes, 2002.

HEBDIGE, Dick. Subcultura: El significado del estilo. Barcelona, Buenos Aires, México, Paidó. 2004.

JACQUEMET, Marco. "Verbal Conflict." In Encyclopedia of Language and Linguistics, vol. 9. Ed. by K. Brown. 2nd ed. London: Elsevier. pp. 4915-21.

LEDRUT, Raymond. La forme et les sens dans la société. Paris: Méridiens, 1984.

MACHADO, Giancarlo Marques Carraro. De "carrinho" pela cidade: a prática do street skate em São Paulo. 2011. Dissertação (Mestrado em Antropologia Social) - Faculdade de Filosofia, Lestras e Ciências Humanas, Universidade de São Paulo, São Paulo, 2011. Disponível em: http://www.teses.usp.br/teses/disponiveis/8/8134/tde-05062012-160404/>. Acesso em: 2016-05-17

MAGNANI, José Guilherme Cantor. Os circuitos dos jovens urbanos. Tempo Social, 17(2), 173205, 2005.

MAGNANI, José Guilherme Cantor. Da periferia ao centro: trajetórias de pesquisa em Antropologia Urbana. São Paulo: Terceiro Nome, 2012

MAGNANI, José Guilherme Cantor. Festa no Pedaço: Cultura popular e lazer na cidade. São Paulo: Unesp, 2003

MÁRQUEZ , Israel; DÍEZ García, Rubén. La cultura skate en las sociedades contemporáneas: una aproximación etnográfica a la ciudad de Madrid.EMPIRIA. Revista de Metodología de Ciencias Sociales. N.o 30, enero-abril, 2015, pp. 133-158. ISSN: 1139-5737, DOI/empiria.30.2015.13888

OLIC, Mauricio Bacic , « "De quebrada para quebrada": por uma nova cartografia dos skatistas na metrópole », Ponto Urbe [Online], 3 | 2008, posto online no dia 31 Julho 2008

PEIRANO, Mariza. A Alteridade em Contexto. In: A Teoria Vivida e outros ensaios de antropologia. Rio de Janeiro: Zahar Editores, 2006, p. 53-67.

PÉTONNET, Colette. A observação flutuante: o exemplo de um cemitério parisiense. Antropolítica, $n^{\circ} .25$, p.99-111. Niterói, 2008

PROJETO NAVISUAL. Autoria de Cornelia Eckert. Atualizado em 2016.

RICOEUR, Paul. A memória, a história, o esquecimento. Campinas, Ed. Unicamp, 2007.

RICOEUR, Paul. O si e a identidade narrativa. O si-mesmo como um outro. Campinas, Papirus, 1991.

RICOUER, Paul. Tempo e Narrativa (Tomo I). Campinas, SP: Papirus, 1994. 
ROCHA, A. L. C. \& ECKERT, C. Etnografia da duração. Porto Alegre, Marcavisual, 2013a

ROCHA, A. L. C. \& ECKERT, C. Etnografia de Rua: estudos de Antropologia Urbana. Porto Alegre: UFRGS, 2013b

ROCHA, A.L.C. "Antropologia das formas sensíveis; entre o visível e o invisível, a floração de símbolos”. In: Horizontes Antropológicos. Antropologia Visual, Ano 1, vol 2, 1995.

ROCHA, Ana Luiza Carvalho da. ECKERT, Cornelia. A preeminência da imagem e do imaginário nos jogos da memória coletiva em coleções etnográficas. Brasília, ABA publicações, 2015.

ROCHA, Ana Luiza Carvalho da; ECKERT, Cornelia. Etnografia com imagens: práticas de restituição. Tessituras, Pelotas, v. 2, n. 2, p. 11-43, jul./dez. 2014.

SANSOT, P. Les formes sensibles de La vie sociale. Paris: Presses Universitaires de France, 1983

SANSOT, P. Poétique de La ville. Paris: Petite bibliotèque Payot, 1996.

SCHUTZ in WAGNER, Helmut R. (Org. e Introdução). Fenomenologia e relações sociais. Textos (escolhidos de Alfred Schutz). RJ, Zahar, 1979

SIMMEL, G. A Metrópole e a Vida Mental, in O Fenômeno Urbano. Organizado por O. G. Velho, pp 11-25. Rio de Janeiro: Zahar Editores, 1979.

SIMMEL. As grandes cidades e a vida do espírito. Mana 11(2): 577-591. 2005.

SIMMEL. Georg Simmel: Sociologia. Col. Grandes Cientistas Sociais, vol, 34. Evaristo de Moraes Filho (org). São Paulo: Ática. 1983 192p.

VELHO, Gilberto. Individualismo e Cultura. Notas para uma Antropologia das sociedades contemporâneas. Rio de Janeiro, Jorge Zahar Editor, 1988.

VELHO, Gilberto. Projeto e metamorfose. Antropologia das sociedades complexas. Rio de Janeiro, Jorge Zahar, 1994.

Recebido em: 31/05/2017. Aprovado em: 01/08/2017. 